\title{
PENERAPAN MODEL PEMBELAJARAN KOOPERATIF TIPE NUMBERED HEADS TOGETHER (NHT) UNTUK MENINGKATKAN HASIL BELAJAR PESERTA DIDIK AGRIBISNIS TANAMAN PANGAN DAN HORTIKULTURA SMK NEGERI 2 SOPPENG
}

\section{Application of Cooperative Learning Model Numbered Heads Together (NHT) To Improve Student Learning Outcomes of Agribusiness of Food Crops and Horticulture SMK Negeri 2 Soppeng}

\author{
Nurmila 1), Husain Syam 2), Nurmila 3). \\ 1)Mahasiswa Program Studi Pendidikan Teknologi Pertanian FT UNM, \\ 2) dan 3)Dosen FT UNM \\ Nurmilaptp@gmail.com
}

\begin{abstract}
ABSTRAK
Penelitian ini adalah penelitian tindakan kelas yang bertujuan untuk mengetahui peningkatan hasil belajar mata pelajaran agribisnis tanaman sayuran dengan menggunakan model pembelajaran Numbered Heads Together ( NHT ) pada peserta didik kelas XIc Agronomi SMK Negeri 2 Soppeng. Subyek penelitian ini adalah peserta didik kelas XIc Agronomi SMK Negeri 2 Soppeng yang berjumlah 19 orang dengan rincian 14 orang perempuan dan 5 orang laki-laki. Teknik pengumpulan data dalam penelitian ini adalah menggunakan lembar observasi, tes tertulis, angket dan dokumentasi. Teknik analisis data dalam penelitian ini adalah analisis kualitatif dan kuantitatif. Hasil dari penelitian ini menunjukkan penerapan model pembelajarn NHT dapat meningkatkan hasil belajar peserta didik kelas XIc Agronomi SMK Negeri 2 Soppeng. Hal ini berdasarkan nilai hasil belajar yang di peroleh peserta didik dari siklus I ke siklus II mengalami peningkatan. Hasil belajar peserta didik pada siklus I dengan nilai rata-rata $79,26 \%$ dengan ketuntasan klasikal $84,21 \%$. Sedangkan hasil belajar peserta didik pada siklus II dengan nilai rata-rata sebesar $94,68 \%$ dengan ketuntasan kelas secara klasikal adalah $100 \%$.
\end{abstract}

Kata Kunci : Hasil Belajar, Numbered Heads Together (NHT).

\section{ABSTRACK}

This research is a classroom action research that aims to know the improvement of learn result the subjects of agribusiness of vegetables crops by using Numbered Heads Together (NHT) learning model on class XIc learners of Agronomy of SMK Negeri 2 Soppeng. The subjects of this study were learners of class XIc Agronomy SMK Negeri 2 Soppeng which amounted to 19 people with details of 14 women and 5 men. Data collection technique in this research is using observation sheet, written test, questionnaire and documentation. Data analysis technique in this research is qualitative and quantitative analysis. The results of this study indicate the application of NHT learning model can improve learning outcomes of learners of class XIc Agronomy SMK Negeri 2 Soppeng. It is based on the value of learning outcomes obtained the learners from cycle I to cycle II has increased. Learners learning outcomes in cycle I with an average value of $79.26 \%$ with classical mastery of class $84.21 \%$. While the learning outcomes of learners in cycle II with an average value of $94.68 \%$ with classical mastery of class is $100 \%$.

Keywords: Learning Outcomes, Numbered Heads Together (NHT). 


\section{PENDAHULUAN}

Pendidikan merupakan salah satu hal penting dalam kehidupan manusia. Pendidikan memiliki peran penting dalam pengembangan kepribadian karena pendidikan bersifat mendidik, mengajar, memfasilitasi, mengarahkan, menilai, mengevaluasi. Pengetahuan, pengalaman manusia akan berkembang melalui pendidikan. Pendidikan juga merupakan salah satu tolak ukur kemajuan suatu bangsa.

Peningkatan mutu pendidikan akan tercapai apabila proses belajar mengajar yang diselenggarakan benarbenar efektif. Proses belajar mengajar akan efektif untuk meningkatkan kemampuan pengetahuan, sikap dan keterampilan yang diharapkan dalam tujuan pembelajaran. Sebab pada dasarnya proses belajar mengajar merupakan inti dari proses pelaksanaan pendidikan secara keseluruhan.

Keberhasilan pendidikan dapat dipengaruhi oleh beberapa aspek di antaranya, kualitas sumber daya manusia yang dapat dilihat melalui proses belajar mengajar. Proses belajar mengajar yang berpusat pada guru (teacher centered) beralih ke proses belajar mengajar yang berpusat ke peserta didik (student centered). Paradigma pembelajaran student centered menekankan pada keaktifan peserta didik dalam pembelajaran sehingga diharapkan mampu meningkatkan hasil belajar peserta didik. Menurut Undang-Undang Republik Indonesia Nomor 20 Tahun 2003 tentang Sistem Pendidikan Nasional pasal 1 ayat 20 bahwa pembelajaran adalah proses interaksi peserta didik dengan pendidik dan sumber belajar pada suatu lingkungan belajar (Anonim, 2008).
Berdasarkan Peraturan

Pemerintah No.19 Tahun 2005 tentang Standar Nasional Pendidikan bahwa proses pembelajaran pada satuan pendidikan diselenggarakan secara interaktif, inspiratif, menyenangkan, menantang, memotivasi peserta didik untuk berpartisipasi aktif, serta memberikan ruang yang cukup bagi prakarsa, kreativitas, dan kemandirian sesuai dengan bakat, minat dan perkembangan psikologis peserta didik. Di samping itu, tentunya dalam proses pembelajaran, pendidik harus memberikan keteladanan. Setiap satuan pendidikan harus melakukan perencanaan, pelaksanaan, penilaian dan pengawasan proses pembelajaran untuk terlaksananya proses pembelajaran yang efektif dan efisien (Sary, 2015). Model pembelajaran menjadi bagian terpenting yang menentukan berhasil atau tidaknya suatu proses pembelajaran. Penyusunan materi tidak secara otomatis mengatasi kesulitan belajar bila tidak ditunjang dengan model pembelajaran yang efektif. Oleh karena itu kreativitas dan inovasi pengajar sangat penting dalam memilih model pembelajaran yang sesuai.

SMK Negeri 2 Soppeng merupakan salah satu sekolah menengah kejuruan yang letaknya strategis karena berada di samping Sekolah Menengah Pertama dan dekat jalan raya. Sekolah ini merupakan satusatunya sekolah menengah kejuruan yang ada di kecamatan Marioriwawo sehingga memiliki banyak peminat. Namun, berdasarkan hasil wawancara dengan kepala sekolah pada saat observasi awal, ada beberapa masalah yang dihadapi di sekolah tersebut di antaranya adalah kurangnya minat belajar peserta didik yang berakibat pada rendahnya hasil belajar peserta didik. Hal 
ini dapat dilihat dari hasil tes awal peserta didik pada materi ruang lingkup tanaman sayuran dan syarat tumbuh, yaitu dari 19 peserta didik hanya ada 5 orang yang memperoleh nilai yang memenuhi kriteria ketuntasan minimal $>75,00$. Sedangkan 14 dari 19 peserta didik memperoleh niali $<75,00$ sehingga peserta didik tersebut dinyatakan tidak tuntas. Dari hasil tersebut dapat diketahui persentase ketuntasan kelas secara klasikal yaitu $26,31 \%$ yang berarti bahwa ketuntasan klasikal yang ditetapkan oleh guru mata pelajaran yaitu $85 \%$ belum terpenuhi.

Berdasarkan hasil observasi awal, metode pembelajaran yang digunakan oleh guru dalam proses pembelajaran adalah metode ceramah yang kurang memberikan kesempatan penuh kepada peserta didik untuk berpartisifasi aktif dalam pembelajaran. Peserta didik cenderung diam dan hanya mendengarkan penjelasan dari guru. Peserta didik malu-malu bertanya ketika ada materi yang belum dipahami yang berakibat pada hasil belajar peserta didik yang rendah. Salah satu upaya yang dapat dilakukan untuk meningkatkan hasil belajar peserta didik adalah dengan penerapan model pembelajaran yang memberikan kesempatan kepada peserta didik untuk berpartisipasi aktif dalam pembelajaran.

Model pembelajaran kooperatif merupakan model pembelajaran yang dilaksanakan secara berkelompok oleh peserta didik dan bersifat heterogen. Dengan pengembangan model pembelajaran kooperatif akan mendorong peserta didik untuk lebih kreatif dalam menyelesaikan tugas, menyampaikan pendapat, menghargai pendapat orang lain, sehingga pencapaian keterampilan proses yang diharapkan akan menjadi lebih berkembang. Model pembelajaran kooperatif dikembangkan untuk mencapai paling sedikit tiga tujuan penting yaitu: prestasi akademik, toleransi dan penerimaan terhadap keanekaragaman dan pengembangan keterampilan sosial (Riyanto, 2012). Pembelajaran kooperatif terdiri dari beberapa tipe salah satunya yaitu tipe Numbered Heads Together (NHT).

Pembelajaran kooperatif tipe Numbered Heads Together (NHT) menekankan pada struktur khusus yang dirancang untuk mempengaruhi pola interaksi peserta didik dan memiliki tujuan untuk meningkatkan penguasaan akademik (Zubaedi, 2011). Model Numbered Heads Together (NHT) merupakan teknik dalam belajar yang memberikan kesempatan kepada peserta didik untuk membagi ide-ide, mempertimbangkan jawaban yang tepat, meningkatkan peserta didik untuk mendengarkan secara cermat dan membuka diri terhadap bermacam pendapat.

Setiap peserta didik dalam pembelajaran Numbered Heads Together (NHT) diberikan tanggung jawab untuk mempelajari materi pelajaran dan menjabarkan isinya dalam sebuah kelompok. Salah satu kelebihan pembelajaran Numbered Heads Together (NHT) adalah dapat memberikan kesempatan kepada peserta didik untuk menggunakan keterampilan bertanya, berdiskusi dan mengembangkan bakat kepemimpinan sehingga dengan penerapan model pembelajaran Numbered Heads Together (NHT) diharapkan mampu meningkatkan hasil belajar peserta didik.

Berdasarkan latar belakang masalah yang telah dikemukakan di atas dan mengacu pada tujuan yang akan dicapai dalam penelitian ini, maka 
rumusan masalah penelitian ini adalah apakah penerapan model pembelajaran NHT dapat meningkatkan hasil belajar mata pelajaran agribisnis tanaman sayuran peserta didik kelas XIc Agronomi SMK Negeri 2 Soppeng?

\section{TUJUAN PENELITIAN}

Penelitian ini bertujuan untuk mengetahui peningkatan hasil belajar mata pelajaran agribisnis tanaman sayuran dengan menggunakan model pembelajaran NHT pada peserta didik kelas XIc Agronomi SMK Negeri 2 Soppeng.

\section{METODE PENELITIAN}

Penelitian ini merupakan Penelitian Tindakan Kelas (Classroom action research). Penelitian Tindakan Kelas adalah suatu perencanaan terhadap kegiatan belajar berupa sebuah tindakan yang sengaja dimunculkan dan terjadi dalam sebuah kelas secara bersama (Sanjaya, 2009). Jadi PTK adalah suatu penelitian yang digunakan untuk mengatasi masalah-masalah yang ada di dalam proses pembelajaran dan upaya untuk meningkatkan proses serta hasil belajar. Desain penelitian yang digunakan adalah model Kemmis dan Mc Taggart (Arikunto, 2016). Desain penelitian ini meliputi 4 tahap yaiyu tahap perencanaan, pelaksanaan, pengamatan dan refleksi yang dilaksanakan secara berulang minimal 2 siklus. Penelitian ini dilaksanakan di SMK Negeri 2 Soppeng yang terletak di Desa Marioriaja, Kec. Marioriwawo, Kab. Soppeng. Penelitian ini dilaksanakan pada semester ganjil tahun ajaran 2017/2018, yaitu pada bulan Juli sampai Agustus.

Subjek penelitian ini adalah peserta didik kelas XIc Agronomi SMK Negeri 2 Soppeng yang berjumlah 19 peserta didik dengan rincian 14 orang perempuan dan 5 orang laki-laki.

Tindakan yang dilaksanakan terdiri dari 4 tahap yaitu perencanaan, pelaksanaan, pengamatan, dan refleksi. Penelitian tindakan kelas ini dilaksanakan dalam dua siklus. Penelitian siklus I dilakukan selama tiga kali pertemuan dan begitupun pada siklus II juga dilaksanakan selama tiga kali pertemuan.

Indikator keberhasilan dalam penelitian ini adalah apabila skor ratarata hasil belajar/ ketuntasan belajar peserta didik mengalami peningkatan dengan skor minimum 75,00 dari skor ideal dan ketuntasan secara klasikal 85 $\%$ dari jumlah peserta didik telah tuntas belajar.

Teknik pengumpulan data yang di pergunakan untuk mendapatkan data yaitu observasi, dokumentasi, tes dan angket. Instrumen pengumpulan data merupakan alat yang digunakan untuk mengumpulkan data sehingga diperoleh data yang valid. Instrumen yang digunakan dalam penelitian ini adalah lembar observasi, tes, angket.

Teknik analisis data yang digunakan dalam penelitian ini adalah teknik analisis kuantitatif dan kualitatif. Analisis kualitatif dilakukan dengan melihat data hasil observasi selama proses pembelajaran. Analisis kuantitatif dalam bentuk statistik deskriptif yang meliputi nilai rata-rata, persentase ketuntasan, tabel frekuensi, nilai minimum dan maksimum yang diperoleh peserta didik pada pokok bahasan yang diajarkan.

Ketuntasan nilai yang diperoleh peserta didik dapat dilihat dari skala kategori ketuntasan yang tertera pada tabel 1 berikut ini: 
Tabel 1

Skala Kategorisasi Ketuntasan

\begin{tabular}{ccc}
\hline No & Kategori & Interval Nilai \\
\hline 1. & Tidak Tuntas & $0-74$ \\
2. & Tuntas & $75-100$
\end{tabular}

Sumber: SMK Negeri 2 Soppeng, 2017

\section{HASIL PENELITIAN}

\section{Hasil Tes Awal (Pre Test)}

Tes awal (Pre Test) dilakukan sebelum proses pembelajaran dengan penerapan model Numbered Heads Together (NHT) tepatnya pada hari Senin 31 Juli 2017. Tes awal bertujuan untuk mengetahui kemampuan awal peserta didik dan untuk mengetahui sejauh mana pemahaman peserta didik tentang materi yang akan diajarkan yaitu ruang lingkup tanaman sayuran dan syarat tumbuh.

Hasil tes awal peserta didik kelas XIc Agronomi SMK Negeri 2 Soppeng dapat dilihat pada tabel 1 .

Tabel 1

Statistik Skor Hasil Belajar Peserta Didik pada Tes Awal

\begin{tabular}{lc}
\hline \multicolumn{1}{c}{ Statistik } & Nilai Statistik \\
\hline Jumlah Peserta & 19 \\
Didik & 100 \\
Nilai Ideal & 82 \\
Nilai Tertinggi & 42 \\
Nilai Terendah & 40 \\
Rentang Skor & 66,13 \\
Skor rata-rata &
\end{tabular}

Sumber: Hasil Tes Awal Peserta Didik, 2017
Berdasarkan data tersebut dapat disimpulkan bahwa tes hasil belajar peserta didik belum memenuhi Kriteria Ketuntasan Minimal (KKM) yang telah ditetapkan yaitu 75,00. Hasil analisis persentase ketuntasan belajar peserta didik pada tes awal dapat dilihat pada tabel 2 berikut ini.

Tabel 2

Distribusi Frekuensi Ketuntasan Belajar Peserta Didik pada Tes Awal

\begin{tabular}{lccc}
\hline Skor & $\begin{array}{c}\text { Frekuens } \\
\text { i }\end{array}$ & $\begin{array}{c}\text { Persentas } \\
\mathbf{e}(\%)\end{array}$ & Kategori \\
\hline $0-74$ & 14 & 73,68 & $\begin{array}{c}\text { Tidak } \\
\text { Tuntas }\end{array}$ \\
$75-$ & & & \\
100 & 5 & 26,32 & Tuntas \\
\hline Jumla & & & \\
h & 19 & 100 & \\
\hline
\end{tabular}

Sumber: Analisis Data Tes Awal Peserta Didik, 2017

\section{Hasil Penelitian Siklus I}

Siklus I dilaksanakan dalam empat tahap meliputi tahap perencanaan, pelaksanaan tindakan, pengamatan, dan refleksi.

Data Hasil Tes Siklus I

Data hasil tes peserta didik dapat dilihat pada tabel 4 statistik skor hasil belajar peserta didik pada tes siklus I di bawah ini. 
Tabel 4

Statistik Skor Hasil Belajar Peserta Didik pada Tes Siklus I

\begin{tabular}{lc}
\hline \multicolumn{1}{c}{ Statistik } & Nilai Statistik \\
\hline Jumlah Peserta Didik & 19 \\
Nilai Ideal & 100 \\
Nilai Tertinggi & 92 \\
Nilai Terendah & 63 \\
Rentang Skor & 29 \\
Skor rata-rata & 79,26
\end{tabular}

Sumber: Hasil Post Test Siklus I, 2017

Tabel 4 menunjukkan bahwa skor rata-rata hasil belajar peserta didik pada materi ruang lingkup tanaman sayuran dan syarat tumbuh setelah dilakukan tes pada siklus I adalah 79,26 dari nilai ideal 100 , nilai tertinggi yang diperoleh 92 , nilai terendah 63 dan rentang skor 29.

Apabila kemampuan peserta didik dalam menyelesaikan soal-soal tes siklus I dianalisis, maka persentase ketuntasan belajar peserta didik dapat dilihat pada tabel 5 di bawah ini.

\section{Tabel 5}

Distribusi Frekuensi Ketuntasan Belajar Peserta Didik pada Tes Siklus I

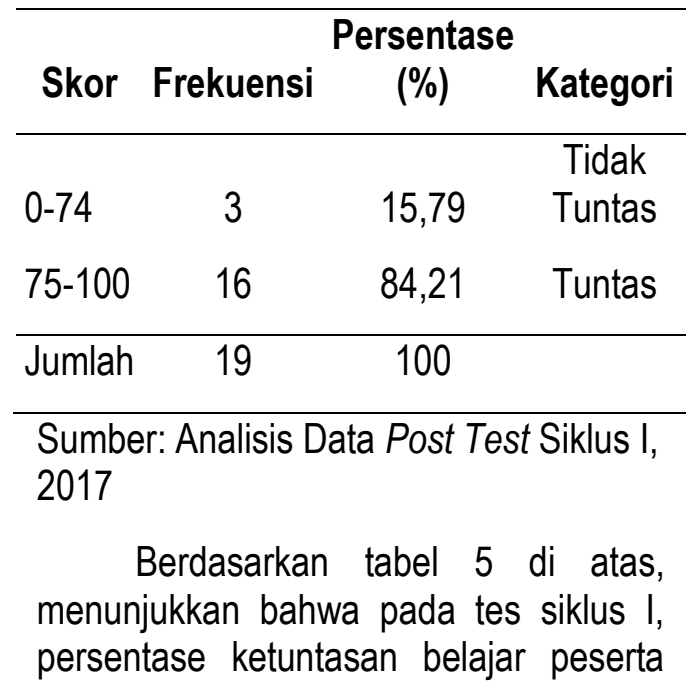

didik sebesar $84,21 \%$ yaitu 16 dari 19 peserta didik termasuk dalam kategori tuntas, sedangkan $15,79 \%$ yaitu 3 dari 19 peserta didik dikategorikan tidak tuntas. Hal ini berarti ketuntasan kelas secara klasikal belum tercapai yaitu $85 \%$ sehingga perlu diadakan tindakan lanjutan atau siklus II untuk mencapai kriteria ketuntasan klasikal yang telah ditentukan tersebut sehingga tujuan dari penelitian dapat tercapai yaitu adanya peningkatan hasil belajar peserta didik.

Data Hasil Observasi Siklus I

Hasil pengamatan aktivitas belajar peserta didik pada siklus I tentang kehadiran dan keaktifan belajar peserta didik kelas XIC Agronomi SMK Negeri 2 Soppeng yang berjumlah 19 peserta didik diperoleh dari lembar observasi pada saat proses pembelajaran dilaksanakan dapat dilihat pada tabel 6 berikut ini. 
Tabel 6

Hasil Observasi Aktivitas Belajar Peserta Didik pada Siklus I

\begin{tabular}{ccccccc}
\hline No & $\begin{array}{c}\text { Komponen } \\
\text { yang }\end{array}$ & \multicolumn{3}{c}{ Pertemuan } & $\begin{array}{c}\text { Rata- } \\
\text { rata }\end{array}$ \\
\cline { 2 - 7 } diamati & 1 & $\%$ & 2 & $\%$ & $3 \%$ \\
\hline
\end{tabular}

1. didik yang

1. hadir

$191001789,47 \quad 184,794,73$

mengikuti

pelajaran.

Peserta

didik yang

2. bertanya

saat

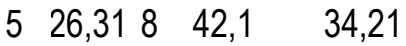

mengalami

kesulitan.

Peserta

didik yang

mampu

3. mempresent

asikan hasil

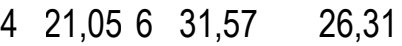

kerja

kelompokny

a.

Peserta didik yang

4. menanggapi

jawaban dari

kelompok

$5 \quad 26,317 \quad 36,84$

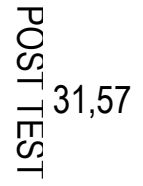

lain.

Peserta

5. didik yang

5. aktif

mengumpul

kan tugas.

$1789,471894,73$

Peserta

didik yang

melakukan

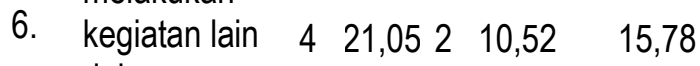

dalam

proses

pembelajara

$\mathrm{n}$.

Sumber: Lembar Observasi Aktivitas

Peserta Didik Siklus I, 2017
Tabel 6 di atas menunjukkan bahwa semua peserta didik hadir pada siklus I pertemuan pertama. Peserta didik yang bertanya saat mengalami kesulitan sebanyak 5 orang. Peserta didik yang mampu mempresentasikan hasil kerja kelompoknya sebanyak 4 orang. Peserta didik yang memberikan tanggapan terhadap jawaban dari kelompok lain ada 5 orang dan peserta didik yang aktif mengumpulkan tugas sebanyak 17 orang serta ada 4 orang peserta didik yang masih melakukan kegiatan lain dalam proses pembelajaran.

Selanjutnya pada pertemuan kedua siklus I terdapat 17 peserta didik yang hadir mengikuti proses pembelajaran. Ada 8 peserta didik yang bertanya saat mengalami kesulitan. Peserta didik yang mampu mempresentasikan hasil kerja kelompoknya sebanyak 6 orang dan terdapat 7 orang peserta didik yang menanggapi jawaban dari kelompok lain. Sedangkan peserta didik yang aktif mengumpulkan tugas sebanyak 18 namun masih ada 2 orang peserta didik yang melakukan kegiatan lain dalam proses pembelajaran.

\section{Hasil Penelitian Siklus II}

Pembelajaran pada siklus II dilaksanakan untuk memperbaiki tindakan dari siklus I. Pelaksanaan tindakan siklus II sama halnya dengan tindakan siklus I yaitu dengan mengacu pada empat tahap, yaitu perencanaan, pelaksanaan tindakan, pengamatan dan refleksi.

Data Hasil Tes Siklus II

Data hasil tes peserta didik dapat dilihat pada tabel 9 statistik skor hasil belajar peserta didik pada tes siklus II di bawah ini. 
Tabel 7

Statistik Skor Hasil Belajar Peserta Didik pada Tes Siklus II

\begin{tabular}{lc}
\hline \multicolumn{1}{c}{ Statistik } & Nilai Statistik \\
\hline Jumlah Peserta Didik & 19 \\
Nilai Ideal & 100 \\
Nilai Tertinggi & 100 \\
Nilai Terendah & 86 \\
Rentang Skor & 14 \\
Skor rata-rata & 94,68 \\
\hline
\end{tabular}

Sumber: Hasil Post Test Siklus II, 2017

Tabel 7 menunjukkan bahwa skor rata-rata hasil belajar peserta didik pada materi ruang lingkup tanaman sayuran dan syarat tumbuh setelah dilakukan tes pada siklus II adalah 94,68 dari nilai ideal 100 , nilai tertinggi yang diperoleh 100 , nilai terendah 86 dan rentang skor 14 .

Apabila kemampuan peserta didik dalam menyelesaikan soal-soal tes siklus II dianalisis, maka persentase ketuntasan belajar peserta didik dapat dilihat pada tabel 8 di bawah ini.

\section{Tabel 8}

Distribusi Frekuensi Ketuntasan Belajar Peserta Didik pada Tes Siklus II

\begin{tabular}{lccc}
\hline Skor & Frekuensi & $\begin{array}{c}\text { Persentase } \\
(\mathbf{\%})\end{array}$ & Kategori \\
\hline $0-74$ & 0 & 0 & $\begin{array}{c}\text { Tidak } \\
\text { Tuntas }\end{array}$ \\
$75-100$ & 19 & 100 & Tuntas \\
\hline Jumlah & 19 & 100 & \\
\hline
\end{tabular}

Sumber: Analisis Data Post Test Siklus II, 2017

Berdasarkan tabel 8 di atas, menunjukkan bahwa pada tes siklus II, persentase ketuntasan belajar peserta didik sebesar $100 \%$ yaitu 19 dari 19 peserta didik termasuk dalam kategori tuntas atau semua peserta didik mendapatkan nilai hasil belajar $>75$ dan termasuk dalam kategori tuntas. Hal ini berarti ketuntasan kelas secara klasikal telah tercapai yaitu $85 \%$ sehingga tidak perlu diadakan tindakan lanjutan atau siklus III karena ketuntasan klasikal yang telah ditentukan tersebut telah dicapai sehingga tujuan dari penelitian dapat tercapai yaitu adanya peningkatan hasil belajar peserta didik.

Data Hasil Observasi Siklus II

Hasil pengamatan aktivitas belajar yang dilakukan pada siklus II tentang kehadiran dan keaktifan peserta didik kelas XIc Agronomi SMK Negeri 2 Soppeng yang berjumlah 19 orang diperoleh dari lembar observasi pada saat proses pembelajaran berlangsung dapat dilihat pada tabel 4.9 berikut ini: 
Tabel 9

Hasil Observasi Aktivitas Belajar Peserta Didik pada Siklus II

\begin{tabular}{llllllll}
\hline & Komponen & \multicolumn{2}{c}{ Pertemuan } & $\begin{array}{c}\text { Rata- } \\
\text { rata }\end{array}$ \\
\cline { 3 - 7 } & diamati & 1 & $\%$ & 2 & $\%$ & 3 & $\%$
\end{tabular}

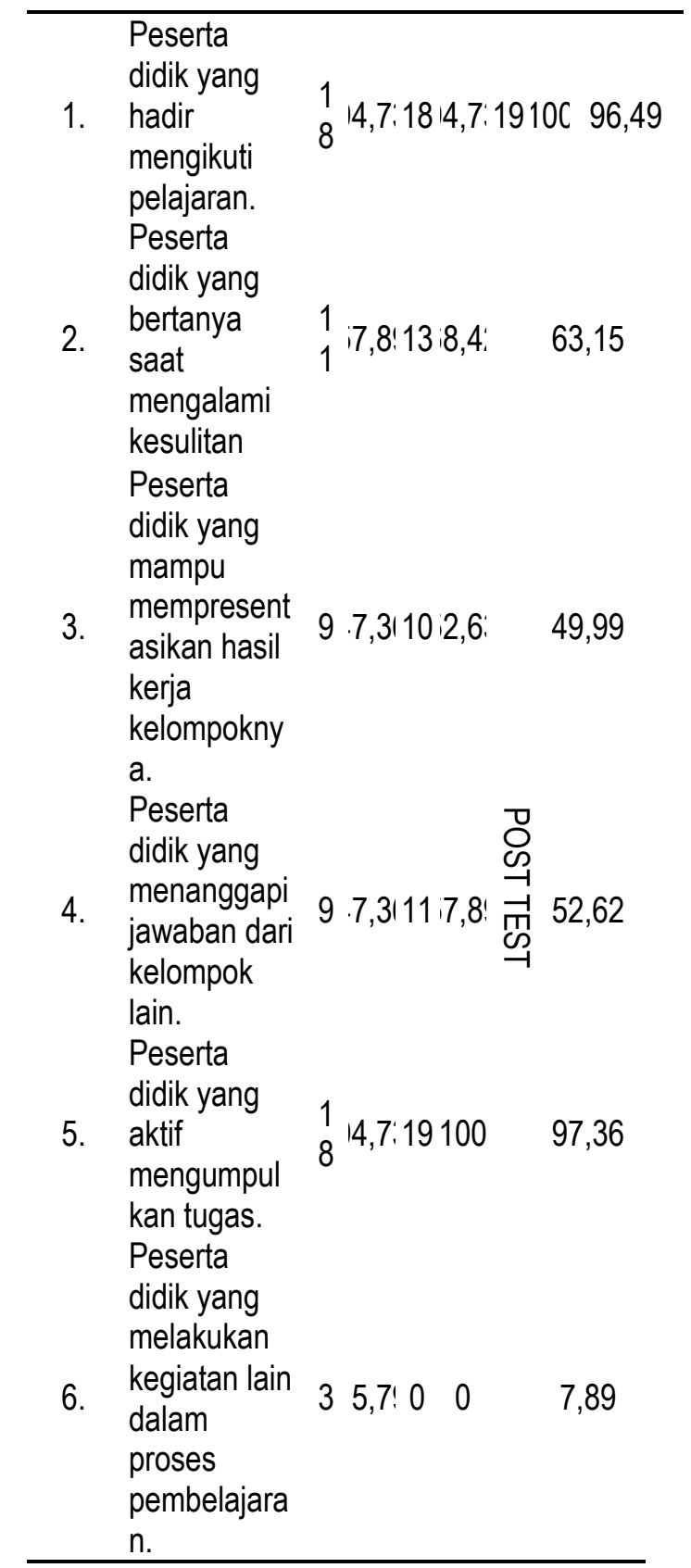

Sumber: Lembar Observasi Aktivitas Peserta Didik Siklus II, 2017

Tabel 9 di atas menunjukkan bahwa 18 peserta didik hadir pada siklus II pertemuan pertama. Peserta didik yang bertanya saat mengalami kesulitan sebanyak 11 orang. Peserta didik yang mampu mempresentasikan hasil kerja kelompoknya sebanyak 9 orang. Peserta didik yang menanngapi jawaban dari kelompok lain ada 9 orang dan peserta didik yang aktif mengumpulkan tugas sebanyak 18 orang serta ada 3 orang peserta didik yang masih melakukan kegiatan lain dalam proses pembelajaran.

Selanjutnya pada pertemuan kedua siklus II terdapat 18 peserta didik yang hadir mengikuti proses pembelajaran. Ada 13 peserta didik yang bertanya saat mengalami kesulitan. Peserta didik yang mampu mempresentasikan hasil kerja kelompoknya sebanyak 10 orang dan terdapat 11 orang peserta didik yang memberikan tanggapan terhadap jawaban dari kelompok lain. Sedangkan peserta didik yang aktif mengumpulkan tugas sebanyak 19 dan pada pertemuan kedua semua peserta didik aktif dan memperhatikan pembelajaran dengan baik sehingga tidak ada peserta didik yang melakukan kegiatan lain.

\section{PEMBAHASAN}

Hasil penelitian yang telah dilakukan dengan penerapan model Numbered Heads Together (NHT) pada materi ruang lingkup tanaman sayuran dan syarat tumbuh menunjukkan adanya peningkatan hasil belajar peserta didik kelas XIc Agronomi SMK Negeri 2 Soppeng. Model Numbered Heads Together (NHT) merupakan model pembelajaran yang memberikan kesempatan kepada peserta didik agar terlibat aktif dalam pembelajaran. Peserta didik dibagi ke dalam beberapa kelompok kemudian diberi tugas untuk dikerjakan secara berkelompok sehingga peserta didik terlibat langsung dalam 
pembelajaran. Dengan penerapan model Numbered Heads Together (NHT) dalam proses pembelajaran menjadikan peserta didik lebih aktif dalam pembelajaran, saling membantu dan saling menghargai pendapat teman serta memiliki rasa tanggung jawab terhadap tugas yang telah diberikan.

Penelitian yang telah dilakukan selama dua siklus menunjukkan adanya peningkatan hasil belajar dan keaktifan peserta didik dalam proses pembelajaran. Berdasarkan hasil angket, peserta didik menyukai model Numbered Heads Together (NHT) karena peserta didik mendapat kesempatan penuh untuk menyampaikan pendapatnya dan bertanya apabila ada materi yang belum dipahami serta melatih rasa percaya diri dan keberanian peserta didik untuk berbicara di depan orang banyak.

Penerapan model Numbered Heads Together (NHT) merupakan salah satu faktor yang menentukan ketercapaian hasil belajar peserta didik, karena penggunakan strategi mengajar yang sesuai dengan materi yang disajikan akan mempengaruhi minat dan aktivitas belajar peserta didik dalam proses pembelajaran yang berpengaruh pada hasil belajar peserta didik.

\section{SIMPULAN}

Berdasarkan hasil penelitian yang telah dilakukan pada tanggal 28 Juli - 21 Agustus 2017 SMK Negeri 2 Soppeng dapat disimpulkan bahwa penerapan model Numbered Heads Together (NHT) dapat meningkatkan hasil belajar mata pelajaran agribisnis tanaman sayuran peserta didik kelas XIc Agronomi dengan persentase ketuntasan pada tes awal yaitu $26,32 \%$ atau 5 dari 19 peserta didik yang tuntas, pada tes siklus I sebesar $84,21 \%$ atau 16 peserta didik yang tuntas kemudian pada tes siklus II persentase ketuntasan peserta didik adalah $100 \%$ atau semua peserta didik dinyatakan tuntas. Peningkatan ketuntasan peserta didik dari tes awal ke siklus I sebesar $57,94 \%$ dan dari siklus I ke siklus II sebesar $15,79 \%$.

\section{DAFTAR PUSTAKA}

Anonim. 2008. Kamus Besar Bahasa Indonesia. Jakarta: Balai Pustaka.

Arikunto, S. 2016. Dasar-dasar Evaluasi Pendidikan. Jakarta: Bumi Aksara.

Riyanto, Yatim. 2012. Paradigma Baru Pembelajaran sebagai Referensi Bagi Pendidik dalam Implementasi Pembelajaran yang Efektif dan Berkualitas. Jakarta: Kencana Prenada Media Group.

Sanjaya, Wina. 2009. Strategi Pembelajaran Berorientasi Standar Proses Pendidikan. Jakarta: Kencana.

Sary, Yessy Nur Indah. 2015. Buku Mata Ajar Evaluasi Pendidikan. Yogyakarta: deepublish.

Zubaedi. 2011. Desain Pendidikan Karakter. Jakarta: Kencana. 